\title{
Assessing the Sustainability of Food Retail Business: The Case of Konsum Värmland, Sweden
}

\author{
Addis Bekele, Techane Bosona, Ingrid Nordmark, Girma Gebresenbet, David Ljungberg
}

Department of Energy and Technology, Swedish University of Agricultural Sciences, Uppsala, Sweden.

Email: adiye.bekele@gmail.com

Received September $12^{\text {th }}, 2012$; revised October $16^{\text {th }}$, 2012; accepted October $26^{\text {th }}, 2012$

\begin{abstract}
It is public concern that the impacts of food retail business activities need to be recognized and addressed properly. The main objective of this study was to assess the sustainable business management of a cooperative food retail business in Sweden, known as Konsum Värmland (KV). The necessary data and information on history and status of KV, and its practical activities concerning the implementation of sustainable development principles as well as the motivation and challenges encountered during the implementation were gathered via reviewing different documents, research papers and press releases; interviewing decision makers and other personnel in KV and other researchers who have investigated KV. The implementation of sustainability initiatives was analyzed in depth mainly based on triple bottom line sustainability theory. The findings indicate that KV has incorporated the sustainability issues into its mission and values. It practically has been implementing sustainability programs in environmental, social and economic dimensions. It provides environmentally friendly and quality food products using its main brands names for local products. The major drives for KV to implement sustainability initiatives are leadership and employees' commitment, organizational core values, and members' and consumers' awareness. On the other hand, the major challenges to such sustainability initiatives are high price of greener products, high logistics cost and emission due to long winter time, the seasonality of local product, and high cost of large scale investment.
\end{abstract}

Keywords: Sweden; Konsum Värmland; Food Retailer; Sustainable Business Development; Sustainability Indicators; Triple Bottom Line

\section{Introduction}

During the recent two decades the principles of sustainable development have attracted more attention and impressive progresses have been seen in realization of sustainability principles in environmental, social and economic dimensions in different sectors including food and agriculture sectors [1]. According to World Commission on Environment and Development (WCED), sustainable development is "development, which meets the needs of the present without compromising the ability of future generation to meet their own needs" [2]. Sustainability issue is too complex to fully understand and easily implement [3]. Sustainable development encompasses a balanced approach for economic growth, environmental justice and social equity [4]. Business firms and corporations have understood the need to address the sustainability issues and consider their relationship with consumers, supply chain networks, stakeholders and providers of business solutions in order to create sustainable solutions and performances [5,6].

Food retail business (FRB) operation is one of busi- ness areas where the concept of sustainability is being addressed. FRB makes a lot of contributions for the economic growth and employment opportunities in Europe where food retailers are becoming large corporations because of merger and acquisition trends. According to confederation of the food and drink industries of the EU [7], although the experience and consolidated markets of food retailers differ significantly in European member states, the trend in general is towards larger stores and hypermarkets. For example, the Swedish food retail market has been the most consolidated one, up to $91.7 \%$ shared between four to five actors in the sector and the situations in other countries like Germany, France and Netherlands have shown the same trend. Even though there are fewer players in the new food marketing system, the food system is more consumer-driven than before [8]. Food retailers are important players to utilize resources wisely and to reduce impacts on the environment and society [9]. Because, they have good economic size and strategic position between the manufacturers and consumers, influence on the supply chain, constructive and 
negative role on the society and the natural environment, and their ability in shaping up the consumer behavior.

In developed countries in Europe and North America, approximately $27 \%$ of cereals and up to $33 \%$ of fish and seafood are lost at consumption level [10]. WCED [2] states "unsustainable patterns of consumption and production particularly in industrialized countries are major cause of global environmental degradation”. After fifteen years, this report becomes the basis for international and European policy on sustainable business development.

Business companies have to assess their operational impact on the environment and society and adopt strategic sustainable program. However, there are no well established standards for assessing the sustainability of such business firms and there is no well defined standardized way of reporting [11]. As the awareness of the society on sustainability issue is increasing, the society expects more sustainability reports and companies need to produce trustworthy and accessible reports.

The main objective of this study was to carry out sustainability assessment of Konsum Värmland (KV). The assessment was targeted to identify the major sustainability indicators for successful sustainable business development (SBD) and investigate the progress of $\mathrm{KV}$ in implementing its sustainable business development strategy; to know how Konsum Värmland incorporates sustainability principles in its business operation; and to identify the main motivations and challenges encountered $\mathrm{KV}$ during the implementations of sustainable business development principles.

\subsection{Sustainable Business Development}

Due to the demands from the internal and external pressures, companies are trying to transform the traditional management approach to a dynamic and fully interconnected management system to involve stakeholders, consumers and innovative environmental friendly technologies in the management process. The customer, the media and the society at large expect good supply networks, allies and cooperation whether it has direct or indirect tie to the company. Leading companies started to take action to incorporate the sustainability principles, into their strategic business development [12]. In general sustainable development perception has different stages, and it embraces political opinions and various scholarly perspectives. SBD integrates the economic, social and environmental viewpoints which could be described with triple bottom line (TBL) theoretical frame work.

\subsection{Triple Bottom Line}

The term triple bottom line (TBL) refers to "simultaneous pursuit of economic prosperity, environmental quality, and social equity" [13]. The notion behind the triple bottom approach is to measure companies' performance not only by using traditional bottom line (the economic aspect) that would not show the whole picture of the company's performance, but also by its environmental and social performance [12,14]. Figure 1 presents the conceptual framework of TBL.

\subsubsection{Environmental Sustainability}

The urgency to protect and conserve the natural environment became the major values embraced by most leading companies [15]. Companies set environmental strategies to forecast and measure the impacts of their operational activities on the environment and start to take actions to significantly reduce waste and environmental pollution in advance and to take the positive business opportunities [16]. Moreover, companies started to realize the government environmental regulatory as competive business opportunity and try to capitalize on the environmental performance [17].

Proactive environmental management involves five key approaches [16,18-20]. These are: 1) waste minimization and prevention (material substitution, process modification, material reuse within the existing processes, materials recycling to a secondary processes and material reuse within a different process); 2) demand-side management (providing products that are demanded by customer and increasing awareness of customer to use services and products efficiently); 3) design for environment (including environmental concerns at the early steps of product and service design to eliminate or decrease environmental wastes associated with the process and design); 4) product stewardship (considering the "takeback "law which requires the product manufacturers to take care of the products and packaging materials at the end of the product life); and 5) full cost environmental accounting (taking into account direct costs such as labor, capital, and raw materials; hidden costs such as monitoring and reporting costs; contingent liability costs such as costs of fines and remedial action; and less tangible costs such as public relations and Good will.

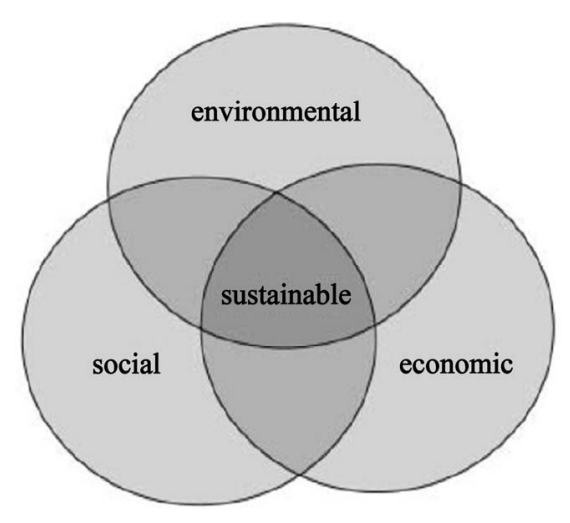

Figure 1. Triple bottom line parameters. 


\subsubsection{Social Responsibility}

It is the benefit of the business firm, in the long term, to act as socially responsible corporate [21]. This is the argument usually stated in the concept of corporate social responsibility (CSR) which has been in the literature for decades [22,23]. The CSR concept addresses the crucial relationship between the society and business. Business firms should anticipate and act to engage in CSR to address the concerns of the community, stakeholders, and the employees in addition to their profit pursuit.

The social responsibility of corporations could be conceptualized from four points of views i.e. economic (making profit without compromising the stakeholders' interest), legal (making profit while operating according to the laws and regulations), ethical (avoiding activities that are rejected by society) and the philanthropic responsebilities (responding to societal demands voluntarily with the corporation discretion).

To address the social injustice in the work place and improve the working condition, International Standard Organization (ISO) has designed ISO 26000 for social responsibility [24]. ISO 26000 is intended to enable business firms to have positive impact in sustainable development. It addresses seven core subjects and many issues as presented in Table 1.

There are also some arguments against CSR [25,26]. These are: profit maximization (a business firm is responsible to maximize the profit of shareholders and social concerns should be the issue of government who collects taxes); lack of expertise (Business firms lack the necessary expertise to address the social issues); competition (some firms consider that engagement of business firms in the social problem makes them weak in global competition, excessive power (business firms have already economical and social power and they shouldn't be given additional responsibility to control and shape the society).

Table 1. Core subjects and issues of social responsibility addressed in ISO 26000.

\begin{tabular}{|c|c|}
\hline Core subjects & Description \\
\hline CS1 & Organizational governance \\
\hline CS2 & Human rights \\
\hline CS3 & Labor practices \\
\hline CS4 & Environment \\
\hline CS5 & Fair operating practices \\
\hline CS6 & Consumer issues \\
\hline CS7 & Community involvement and development \\
\hline
\end{tabular}

\subsubsection{Economic Sustainability}

Even though business sustainability is currently accepted to be a combination of economic, environmental and social performances, economic sustainability is the most abstract combination of the three pillars of sustainability. Global reporting initiative (GRI) defined the economic sustainability as "an organization's impact on the economic circumstances of its stakeholders and on the economic systems at the local national and global levels". Therefore, the GRI economic sustainability indicators such as profits emphasize on the economic impact of the firms on the society and the flow of resources among different stakeholders [27].

From environmental and social management point of view, there are two ways to address the issue of economic sustainability. The first begins with the issue of how business can survive and this approach evaluates the inside of the organization. This view focuses on brand reputation and corporate sales as a main goal for economic sustainability [28]. The second approach considers the economic impact of the organization on the economic system or on the society from stakeholder point of view. It investigates how the external environments affect the organization sustainability.

\subsection{Sustainability Indicators of a Business Company}

In 21st century a sustainable company should evaluate its progress in implementing its sustainability programs. However, organizing the important information is a challenge to develop sustainability metrics/indicators. Concerning the environmental sustainability, some of recommended metrics/indicators are: material intensity, energy intensity, toxics released per unit of products or services, and greenhouse gas intensity. Some of indicators of social sustainability are: leadership and employee commitment, job creation and training program, health protection and risk management, and addressing gender distribution in employment program. Similarly, the economic sustainability indicators include turnover and net profit, employee's financial benefit, firm's investment potential, market potential, and funding societal developmental projects.

\section{Methodology}

\subsection{Study Area}

In this study, Konsum Värmland has been studied focusing on sustainability issues. Konsum Värmland is a cooperative association founded in 1903 and one of effective food retailing companies in Sweden. The outlets and subsidiary companies are located within the region of Värmlands, Örebro and Västra Götalands region. The stores are located around the city of Karlstad, the biggest 
city in the region of Värmlands [29]. Konsum Värmland firm has its head office in Karlstad (see Figure 2).

\subsection{Data Collection}

The necessary data and information on history and status of $\mathrm{KV}$ and its practical activities concerning the implementation of sustainable development programs were gathered via reviewing different documents, research papers and press releases by $\mathrm{KV}$; interviewing decision makers and other personnel in $\mathrm{KV}$ and other researchers from Swedish University of Agricultural University who investigated $\mathrm{KV}$. In addition, information regarding the motivation and challenges encountered by KV during the implementation of sustainability initiatives was collected and discussed. To collect primary data in this project, a questionnaire was designed and sent to responsible person at KV. The answers and related information (such as important websites where valuable documents are available) were received through email and telephone conversions.

To identify the pertinent conceptual frame work, a literature review was conducted. Most of the literature searches were undertaken using electronic databases via computer networks of Swedish university of agricultural sciences and the keywords used were sustainable business development, food retailer, environmental friendly products, fair-trade business, local food, social responsibility, and Konsum Värmland. This study was based mainly on qualitative case study research method. Triple Bottom Line theoretical frame work has been used to analyze the status of $\mathrm{KV}$ from sustainability point of view. Figure 3 presents the graphical representation of the concept used in this study approach.

\section{Empirical Findings}

The Swedish food retail sector is more integrated and concentrated and as the common trend in Europe, the sector has been owned and run by few actors and owners of food retailers. Changes in social demographics and life style of consumers towards a single person household have an impact on the retailing business. The retailers are working towards meeting the demands of the consumers by providing healthier alternative products, home meal substitutes and ready to consume food items. The Swedish food consumers demand nutritious, fresh and organic foods. In addition to high quality food items, the consumers demand to know the traceability and environmental issues associated with supply of the food products.

\subsection{Market Structure}

The Swedish food market structure is characterized by low degree of market internationalization and firmly sta-

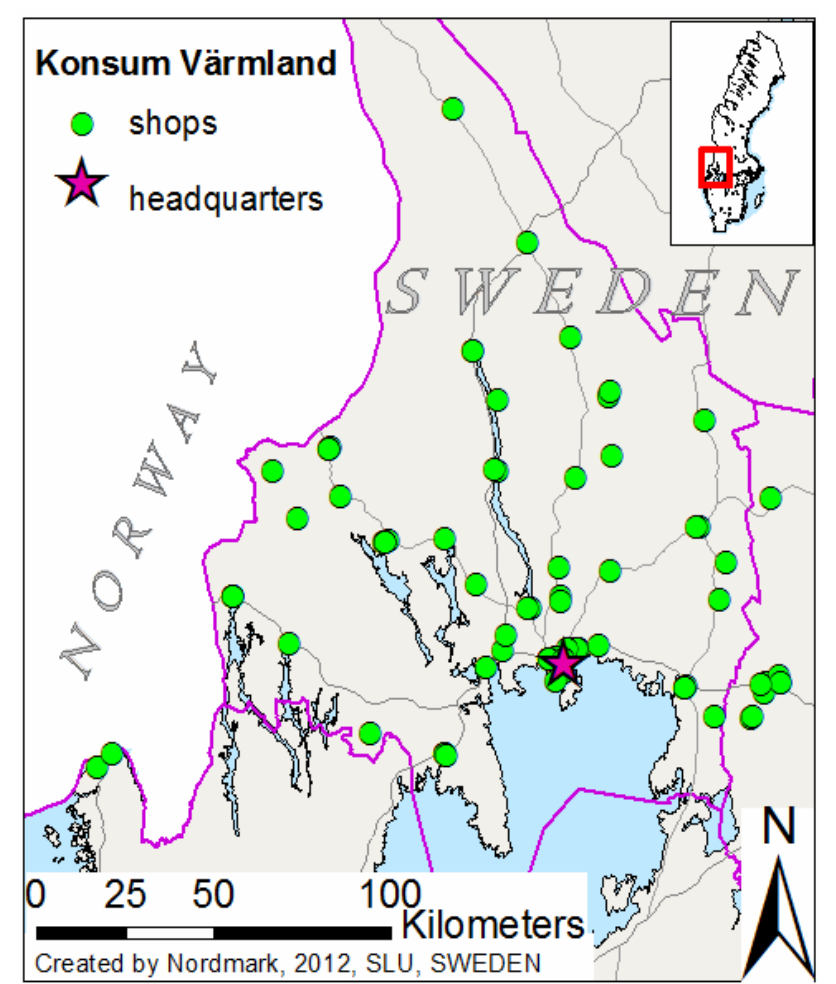

Figure 2. Geographical distribution of Konsum Väarmland shopes.

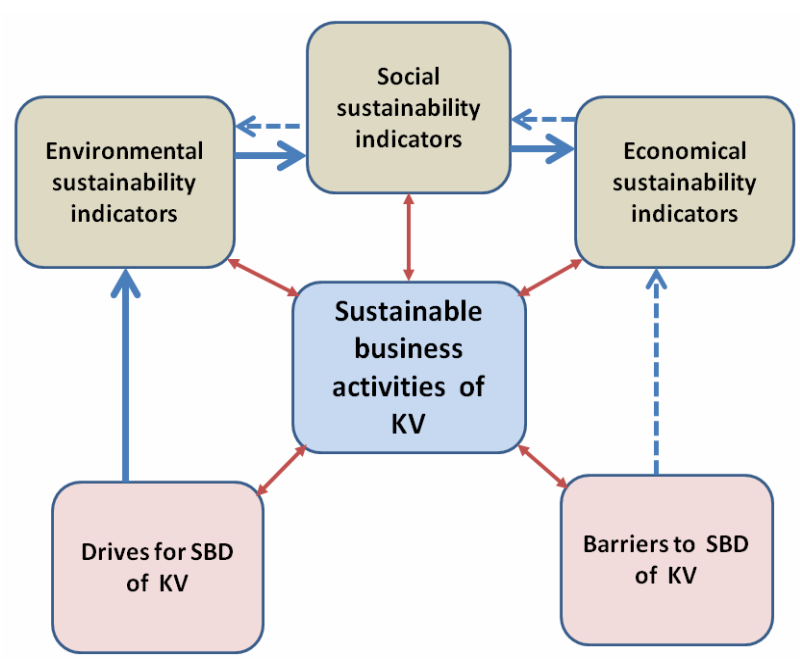

Figure 3. Conceptual representation of the study approach used to assess the sustainable business development (SBD) of Konsum Värmland (KV).

ble market. However, there is increasing competition because food retailers from other region such as Ahold, which has 50\% percent interest in the major retailers of ICA and Lidl, have entered into the Sweden food retail market. To overcome such international competition, the retailers need to reduce the operation cost, by coordinating central procurement activities that will definitely catch the benefit of economics of scale and volume dy- 
namics.

The Swedish food retail and whole sale activity is controlled mainly by three retailers ICA, COOP, and AXFOOD (see Figure 4). Altogether they account above $90 \%$ of the food retailing market. Regional retailer Bergendahlsgruppen which actively works in southern Sweden, covers about $5.7 \%$ of the market share.

ICA Group is a food retail company operating widely in northern Europe. It has around 2125 of its own and retailer-owned stores in Sweden, Norway, Estonia, Latvia and Lithuania. COOP is owned by a cooperative union, a group known as Kooperativa Förbundet (KF) in Sweden. KF is a federation of 42 consumer cooperative societies in Sweden, with over 3 million individual members. $\mathrm{KV}$ is one of these 42 owners of KF. Coop accounts for 20.4 percent of the entire Swedish grocery retail sector.

AXFOOD is a group running food retail and wholesale trade in Sweden. It owns about 237 stores and a large number of proprietors (about 840 proprietors) and runs stores that are tied to Axfood through agreements. Axfood has about $16 \%$ share of the food retail market in Sweden. Bergendahls Gruppen is a company owned by a family. The company started in 1922, and currently it has a food market share of $5.7 \%$ in Sweden.

\subsection{Characteristics of Konsum Värmland}

Konsum Värmland is distinct in Sweden that it involves both the retailing and whole selling business, provides its own broadest range of proprietary and locally produced brands, it has production facilities and ensures quality that the products meet the requirement of the customers and helps in strengthening its brand names. In 2010, Konosum Värmland had a market share of $53.7 \%$, in the Värmland region. It has 145,000 members (one member/house hold), which represent over $90 \%$ of the region's population. In 2011, it had recorded a turnover close to

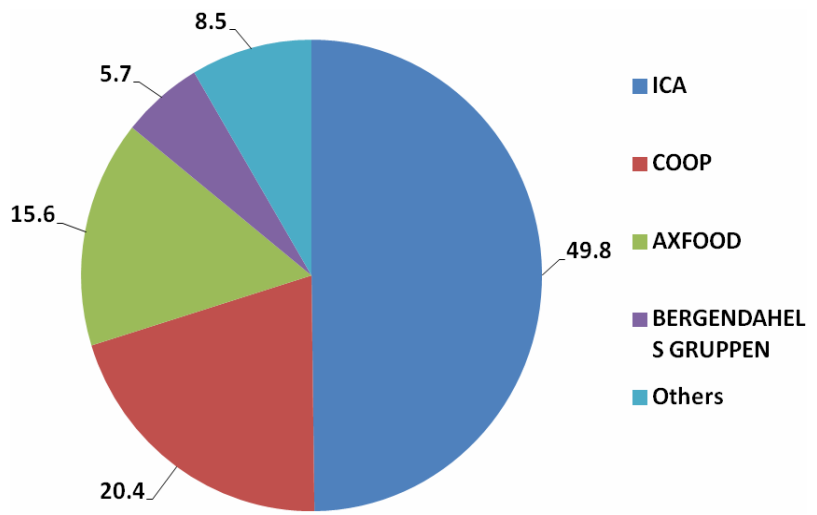

Figure 4. Market share of major food retailers in Sweden. The market share is expressed in percentage of total food market in Sweden.
3.9 billion Swedish kroner. KV provides fair-trade labeled items to consumers. This allows producers in other areas of the Globe the opportunity to improve their lives. Many farmers in developing world are struggling to get a fair price and market for their products. Fair trade works to improve the economic condition, to fight child labor and discrimination and promote ecological and environmental protection (www.fairtrade.org.uk).

\subsection{Konsum Värmland from Sustainability Point of View}

The findings in this study indicate that there are strong efforts towards implementing sustainable development initiatives at both KF and KV levels. The KF works towards sustainable development. In 1899, KF's aim was to help its member organizations to sell pure and unadulterated/unmodified goods at good prices. It has increased its effort and in 2009, this was stated (KF, 2011) as "KF adopts policy on sustainable development, with operational objectives, among others, mitigating climate change".

Positive results have been obtained from the efforts of implementing sustainable development plans. Some of the major successes of year 2010 were: the climate impact from its own operations fell by $44 \%$; $75 \%$ of employees were satisfied with their work situation and with the company's sustainability efforts; the supply of organic and eco-labeled food items increased by $10 \%$; and 23.6 MSEK was collected to support the poverty reduction activities of two organizations, "Kooperation Utan Gränser" and "Vi-skogen”. Since KV is the member of $\mathrm{KF}$, such achievements of KF are also the achievements of KV. However the degree of KV's achievement may differ from that of KF if investigated at the KV company level. Each subsidiary and member company has a responsibility to live up to the sustainability policy and goals of KF. As a member of KF, KV has direct responsibility to implement the sustainable development programs set by KF.

\subsubsection{Environmental Engagement}

Environmental concern refers to activities such as waste reduction, efficient energy usage, emission reduction, efficient water usage and promoting Biodiversity. KV is working on strategies how to lower power usage and refrigerator leak, waste and green gas emission, operating costs, and to improve the waste management procedures.

\subsubsection{Energy Consumption}

Over the recent years $\mathrm{KV}$ has managed to reduce the energy usage and refrigerator leakage. For example it has implemented a new sustainable store design that are environmentally friendly and energy efficient. KV has reportedly improved the efficiency of electricity consump- 
tion from lighting, heating and cooling.

\subsubsection{Waste Reduction, Recycle and Reuse of Packaging Materials}

$\mathrm{KV}$ has gained good experience than its competitors in managing plastic and paper waste such as collecting and sorting of packaging and other recyclable materials like corrugated cardboard cartons, plastic packaging and plastic film. The collected materials are sent to KV Värmlands environmental station, where, specially trained staff makes quality assessment before transporting to the final recovery process.

KF members have tightened their commitment to reduce their environmental impact on the climate and have set a goal to decrease the carbon emission from their activities up to $40 \%$ by year 2020 taking year 2008 as reference. To get better result on environmental performance the coop invests more on efficient energy technology focusing on reducing energy consumption of stores, freight transport and coolants and refrigerators plants.

The main reasons that increase the emission from transport sector of KF member firms are longer winter season with heavy snow, longer transport distance, and increased transport activities to avoid delay in supply chain. The second largest greenhouse gases emissions in business operations come from the refrigerator plant in stores and at the terminals and this emission should be reduced. For example, in the case of $\mathrm{KV}$, the leakage decreased during the year 2011 from 13\% to 10\%. Leakage has been common in the retail industry and solutions are underway to overcome the issue.

\subsubsection{Environmental Friendly Food Products}

In years 2011 and year 2012, COOP retailers have been branded by Swedish consumers as the most sustainable brand in Sweden. KV has KRAV certified grocery stores offer consumer thousands of organic, natural and environmental friendly products increasing the organic choices such as KRAV certified products (www.krav.se). KRAV stands for sound natural environment, good health, social responsibility, and animal welfare. The KV stores provide Swedish broadest range of sustainable alternative products in the form eco-labeled, fair trade labeled products that are free from chemical pesticides, fer- tilizers and genetically modified organisms.

\subsubsection{Product Quality and Brand Names}

Food suppliers of KV should follow sustainable business practices. They have to provide documents and implement self control and self inspection practices that includes cleaning schedule, temperature control, personnel hygiene, pest control, staff training, water supply etc. Furthermore, suppliers have to document and implement total quality management in accordance with ISO 9000, hazard analysis and critical control points (HACCP) and British retail consortium (BRC). The contractor shall comply with industry agreements regarding the origin and the European parliament and council regulation (EC) no. 17602000 on the labeling of beef and beef products and other Swedish legislation on the handling of food.

Konsum Värmland is well known brand in the region. In addition to its top brand-name, Konsum Värmland, it uses other brands such as Värmlandsgris (sourcing pigs from 32 farms in Värmland), Värmlandslamm (sourcing sheep from 28 farms in Värmland), Värmlandskött (sourcing cattle from 14 farms in Värmland), Nästgård (sourcing products mainly from Värmland) and Svenska favoriter (supplying meatballs) (see Figure 5).

\subsubsection{Animal Welfare and Meat Quality Control}

$\mathrm{KV}$ controls animal welfare and meat quality. It performs inspection in cooperation with independent and competent organizations such as Agricultural Society of Värmland and Animal Rights Alliance. For Example in 2009, four of the farms that deliver pigs to Värmlandsgris were identified as farms that undermined animal welfare issues and banned from supplying to Värmlandsgris. The farmers are also very cooperative to such quality controlling activities.

The aforementioned local brands (see Figure 5) which supply animals to KV shops are known for their high quality meat which has been guaranteed due to the following factors:

$>$ The farms are inspected and open to be visited by consumers and workers in the abattoir.

> Animal handling on farm and during transport follows the Scan AB's animal care program and doesn't affect the welfare of animals.

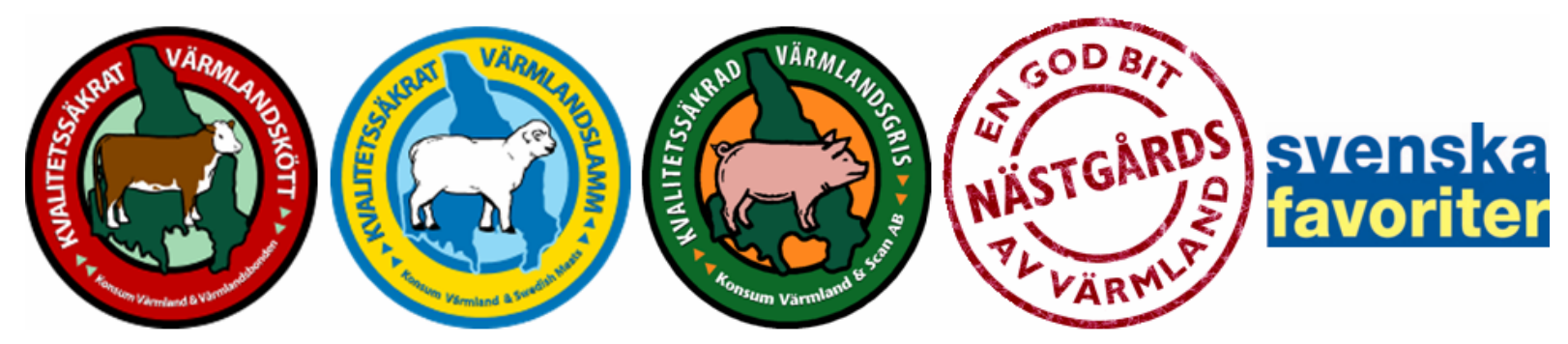

Figure 5. Local brand names of Konsum Värmland (www.Konsumvarmland.se). 
Only well matured animals are supplied for slaughter and

$>$ All animals are kept untied.

\subsubsection{Social Engagement}

For more than 100 years, the values of KV reflect important issues like member ownership, honesty, innovation, and concern for human and environment. In addition to working towards members' benefits by providing products with good quality and relatively less price, KV promotes the suppliers commitment towards environmental and social practices and strengthens stakeholders network that encourages the local farmers.

\subsubsection{Fair Trade Products}

Konsum varmland supplies and sells a number of fairtrade marked products and the sales of fair-trade goods have been increasing from year to year. Fair trade offers consumers a powerful way to reduce poverty through their everyday shopping. For example, currently COOP retailers in Sweden have approximately 100 fair trade labeled items such as coffee, chocolate, tea drinking chocolate, sugar, jam, honey, vegetables, pasta and oil.

\subsubsection{Supplier's Standards and Business Ethics}

For customers who seek healthy habits and care about how goods and services are produced, the obvious choice is retailer that supplies environmentally friendly products. Product safety of both food and non food items is important. Hence, the KV stores require their suppliers to meet specific requirements and also recognize that the significance of their supplier commitment to environmental and international labor practices.

\subsubsection{Policy for Supplier}

Suppliers of KV should maintain equal opportunity of access to job and right to organize; avoid child labor; avoid discrimination on job (based on the sexual orientation, disability, race, gender, religion, marital status, political affiliation or union membership, and HIV positive); create good working condition; pay minimum wages; and prepare acceptable work schedule.

\subsubsection{Community Activity}

$\mathrm{KV}$ participates actively in developmental activities of the region. KV established the Värmland Environment Fund in 1994 which helps to stimulate environmental activities in the Värmland region. This fund is financed by saving 0.05 SEK from each plastic bag sold, and the fund is open to association, companies or individuals working in the area of implementing environmental programs. During years 1995-2003, this fund financed different environmental projects that mostly engaged young people in Värmland. KV also gives financial support to short and long term environmental projects planned to increase the awareness among children and youth. For this, it works with universities and schools in the region.

\subsubsection{Members and Employees of KV}

$\mathrm{KV}$ has been expanding in number of members which has increased by $44 \%$ over the recent decade. At the end of 2011, it had around 147,000 members. However, the number of employees shows decrease in recent years. For example it decreased from 1800 (in 2005) to 1471 in 2011 most probably due to technological advancement.

Considering the gender distribution of employees, $63 \%$ and 66\% were women in 2010 and 2011 respectively. Similarly, $46 \%$ of the executive management and $33 \%$ of board members were women in both 2010 and 2011. Figure 6 indicates the gender distribution of employees and leadership for recent years.

\subsubsection{Economic Engagement}

\subsubsection{Financial Performance}

Considering the economic performance, the revenue (sales) of KV has been increasing. It increased by 30\% from 2004 to 2008. Its gross profit was 812 MSEK (million Swedish kronor) in 2010 and 744 MSEK in 2011 (see Table 2). In year 2011, KV has paid back dividend of 72 MSEK to its members. It also increased its investment activities. In 2011 alone, it invested about 121 MSEK in building new stores to expand their market share. This enabled KV to achieve an influx of members to the association. The market coverage of $\mathrm{KV}$ in the region increased from 39\% in 1991 to $54.6 \%$ in 2008 (see Table 3). Table 2 and Figure 7 indicate the economic performance of recent years.

\subsubsection{Economic Potential for Human Development}

In cooperation with the region of Värmland and the employment services, Konosum Värmland has a scheme to offer apprenticeship to local young people with the aim of creating job opportunities and strengthen the supply of expertise in the region. Through its investment potential

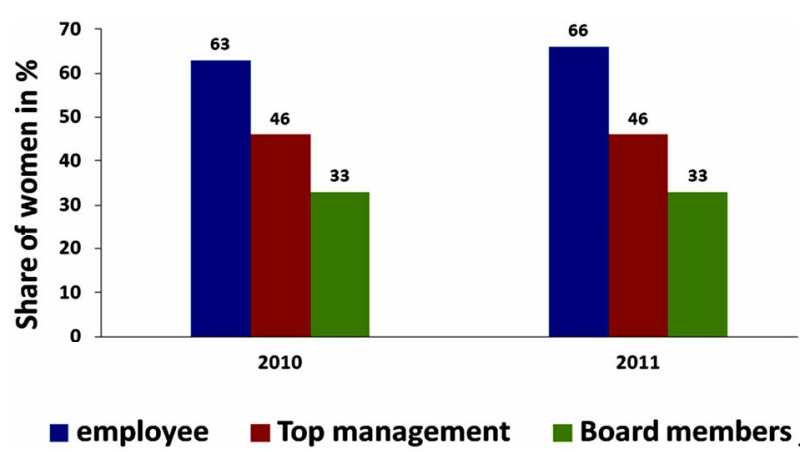

Figure 6. Gender distribution of KV leadership and employees. 
Table 2. Recent financially information of $\mathrm{KV}$ and some food retail firms.

\begin{tabular}{|c|c|c|c|c|c|}
\hline \multirow{2}{*}{ Company } & \multirow{2}{*}{ Description } & \multicolumn{2}{|c|}{2011} & \multicolumn{2}{|c|}{2010} \\
\hline & & MSEK & \% Net sales & MSEK & $\%$ \\
\hline \multirow[t]{7}{*}{ KV } & Net sales & 3532 & & 3649 & \\
\hline & Gross profit & 744 & 21.1 & 812 & 22.3 \\
\hline & Retail operating expenses & 790 & 22.4 & 804 & 22.0 \\
\hline & Selling expense & 776.6 & 22.0 & 795.2 & 21.8 \\
\hline & Administration cost & 13.02 & 0.4 & 9.17 & 0.3 \\
\hline & Other operating costs & - & & - & \\
\hline & Profit after tax & 8.4 & 0.2 & 40.4 & 1.1 \\
\hline \multirow[t]{6}{*}{ ICA } & Net sales & 95,179 & & 93,860 & \\
\hline & Gross profit & 13477 & 14.2 & 13473 & 14.4 \\
\hline & Selling expense & 8435 & 8.9 & 7953 & 8.5 \\
\hline & Administration cost & 2809 & 3.0 & 2819 & 3.0 \\
\hline & Other operating costs & - & & - & \\
\hline & Profit after tax & 1395 & 1.5 & 547 & 0.6 \\
\hline \multirow[t]{6}{*}{ AXFOOD } & Net sales & 34,795 & & 34,260 & \\
\hline & Gross profit & 4918 & 14.1 & 4673 & 13.6 \\
\hline & Selling expenses & 2177 & 6.3 & 2121 & 6.2 \\
\hline & Administration cost & 1736 & 5.0 & 1564 & 4.6 \\
\hline & Other costs & - & & - & \\
\hline & Profit after tax & 895 & 2.6 & 862 & 2.5 \\
\hline \multirow[t]{4}{*}{ Ahold } & Net sales & 30,271 & & 29,530 & \\
\hline & Gross profit & 7921 & 26.2 & 7920 & 26.8 \\
\hline & Retail operating expenses & 6466 & 21.4 & 6471 & 21.9 \\
\hline & Profit after tax & 1017 & 3.4 & 853 & 2.9 \\
\hline
\end{tabular}

Source: [30-33].

$\mathrm{KV}$ promotes local and regional economic growth. It invested about half a billion SEK during 2004-2008 while it invested 121 M SEK only in 2011 (see Table 3). This makes it to be competent in the market and potential firm that promote economic development of the region.

\subsubsection{Economical Development for KV Members}

The basic mission of $\mathrm{KV}$ is to make economic gains for its members. The members' refund varies from $1 \%$ to $5 \%$ and will never be below one percent and awarded according to the purchase they have made in KV stores. In year 2011, it awarded $72 \mathrm{M} \mathrm{SEK}$ to the members. KV also has member bonus scheme which is important, especially for average families who buy most of their purchases from KV stores. The more the member purchases from KV stores, the higher the bonus.

\subsection{Progress of KV in Implementing Sustainability}

The progress of $\mathrm{KV}$ in implementing its sustainable business development strategy was investigated using sustainability indicators. The investigation was carried out considering the three dimensions of SBD. Table 3 presents the summary of sustainability assessment, based on TBL and using the major sustainability indicators.

\subsection{Motivation and Challenges}

The managerial commitment and organizational corevalues have played an important role in pursuing the en- 
Table 3. TBL based assessment of KV's progress in implementing sustainable business development practices.

\begin{tabular}{|c|c|}
\hline Sustainability dimension & Important sustainability indicators identified for Konsum Värmland \\
\hline Environmental Sustainability & $\begin{array}{l}\text { Setting a goal to reduce } \mathrm{CO}_{2} \text { emission from its activities by } 40 \% \text { in } 2020 \text { when compared to } 2008 \text { reference value } \\
\text { Assigning more expenditure on reducing energy consumption } \\
\text { Reducing leakage from refrigerator plants in stores } \\
\text { Having KRAV certificate } \\
\text { Installing (in new shops) coolers and freezers which run in environmental friendly manner } \\
\text { Promoting the supply of local, environmental friendly, quality and fresh products } \\
\text { Promoting the concept of waste minimization at all levels starting from the production level } \\
\text { Promoting animal welfare policy at all levels of supply chain }\end{array}$ \\
\hline Social Sustainability & $\begin{array}{l}\text { Incorporating the concepts of sustainability in the values and mission statement of KV } \\
\text { Commitment of top management to implement sustainability programs } \\
\text { Fair gender distribution i.e. the } 66 \% \text { of employee, } 46 \% \text { of the management, } 33 \% \text { of board members and } 44 \% \text { of } \\
\text { supervisory board (Förvaltningsråd ) are women } \\
\text { High acceptance by consumers who have branded KV as most sustainable food retail company in the region in } 2011 \\
\text { Educating its employees and customers about sustainability issues } \\
\text { Following fair-trade business concepts and currently } \\
\text { KV is a member of KF which produces sustainability report } \\
\text { Promoting the suppliers commitment towards environmental and social practices } \\
\text { Increasing in number of members } \\
\text { Working towards members benefits by providing products with good quality and relatively less price } \\
\text { Arranging members meetings and customers panel, gathering opinions and questions to use effectively for sustain- } \\
\text { able business development } \\
\text { Strengthening stakeholders network that encourages the local farmers } \\
\text { Active participation in societal development through providing funds for different environmental and societal de- } \\
\text { velopmental projects } \\
\text { Reducing the absence due to sickness e.g. reduction from } 9 \% \text { (in 2003) to } 5 \% \text { (in 2009) }\end{array}$ \\
\hline Economic Sustainability & $\begin{array}{l}\text { Increasing revenue (sales). It increased by 30\% from } 2004 \text { to } 2008 \\
\text { Increase in market coverage in the region. E.g. it increased from 39\% in } 1991 \text { to 54.6\% in } 2008 \\
\text { Increase in investment. E.g. it invested about half a billion SEK during 2004-2008. It invested } 121 \text { M SEK in } 2011 \\
\text { which is about } 4 \text { times what it invested in } 2010 \\
\text { Promoting local and regional economic growth } \\
\text { KV has been competitive in market for over } 100 \text { years } \\
\text { Promoting quality products with fair price }\end{array}$ \\
\hline
\end{tabular}

vironmental and social responsibilities. KV strives for member's economic benefit and sustainable consumption which in turn lead towards sustainable business development. For KV, members' willingness to preserve the culture and values of the cooperative and the consumers' awareness about the future trends are among major drives to embrace sustainability.

There are challenges facing KV to reduce the environmental impact of their operation. Product price increases as quality of produce and sustainability of production systems increase. The supply of local product varies seasonally so that it is difficult to satisfy customers need throughout the year. Long winter time with much snow increases the logistics cost and emission values. Different actions taken to reduce environmental impacts of $\mathrm{KV}$ activities require large scale investments. In addition to this, quantifying generated emissions and other wastes and preparing sustainability report require skilled manpower. 


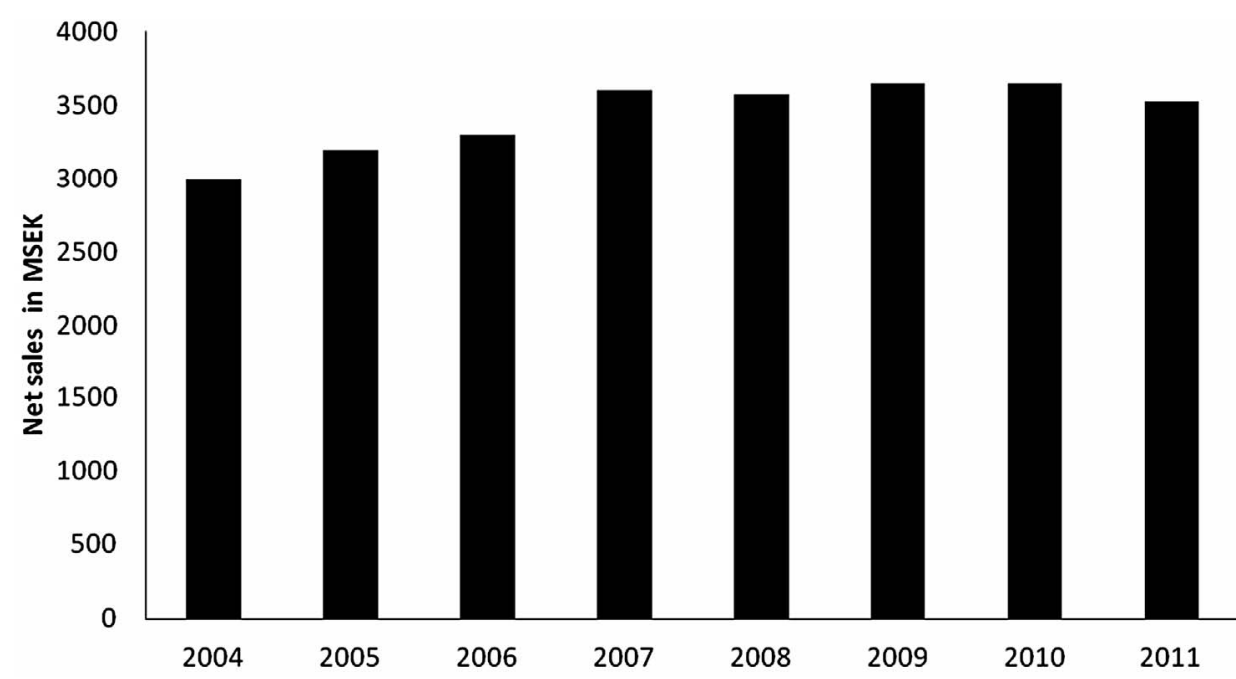

Figure 7. Net sales of KV over the recent years. It shows that the sales increased from 2004, and remains nearly constant after wards.

Greener products are often more costly to produce, and this higher price negatively influences consumer decision-making and reduces potential sales of quality products. Supplying the local products is associated with seasonal problem. It is observed that KV stores have difficulties in meeting a changing demand, and performing all packaging services when the demand increases. The cost of replacing freezers and refrigerators in food retailing business needs a lot of investment and longer time span to reduce the environmental impact.

\section{Discussion}

Contemporary food retailers understand the need to evaluate their operations and address the fact that sustainable business operation goes beyond their mere goal of profit making. There is increasing agreement that retailers have the power to influence the sustainability issues both upstream and downstream of their supply chain. However, integrating sustainability initiatives into their business action plan is not an easy task, especially with the retailers that have a number of supply networks and products [34]. The findings in this study indicate that KV has integrated sustainability principles into its business operations through: incorporating sustainability issues into its mission, values and strategic development plans; providing environmental friendly and quality food products with reasonably less price; strong commitment of leadership towards sustainability issues; increasing awareness of employees, shareholders, stakeholders, and customers about sustainability issues; and maintaining financial profit for shareholders and promoting economic and societal development of the region.

From environmental point of view, KV's brand names promote local products (most of farms are within about $75-100 \mathrm{~km}$ radius) which are easily traceable, require short transport distance and time, and can generate values that attract the customers. KV has KRAV certified grocery stores indicating that the food products are produced using less energy, less fertilizers, less pesticides and less herbicides unlike large scale and mechanized agriculture which use more chemical inputs and pesticides [35,36]. The KF member firms recognize that the environmental effects of their transport activities are huge and they have been reviewing the possible logistics solutions. This indicates that for the coming years, finding best logistics solutions will be one of the main agendas of the KF partners to reduce the environmental impact and increase their economic benefits.

Regarding social sustainability, a company should have critical success factors such as visionary leadership, flexibility to changes and openness to key stakeholders [12]. The leadership of KV is visionary and has commitment to plan and implement sustainable business development practices. It introduced incentive and possible low price products to employees, stakeholders and customers. It also implemented fair gender distribution principle and training programs on sustainability issues (see Figure 6 and Table 3). Zetterberg [37] conducted a value-based assessment of $\mathrm{KV}$ and mentioned that $\mathrm{KV}$ has established values-based thinking and the strong values created by KV can drive value for sustainable business. The current study also confirmed the findings of Zetterberg [37]. KV works to improve health condition of its workers. In order to maintain their market share and remain competitive in the global market, companies must improve the ethical standards and their images, improve the safety concern of personnel, avoid legal claims, respond and cooperate with government regulators.

KV sells fair-trade labeled products sourced from developing countries and this contributes to improved liv- 
ing and working condition of farmers in developing countries. Elder et al. [38] reported that about 1.2 million producers in Latin America, Africa, and Asia supply their products to Fair-Trade certified organizations that sell products across North America and Europe.

Regarding economic sustainability, the core values of a business company are not solely to make profit. The economic growth of business firms should occur without causing social and environmental damages. The finding in the current study indicates that $\mathrm{KV}$ recognizes that sustainable business development demands to fulfill the short and long term interest of different stakeholders satisfying the spirit of sustainability. KV has achieved profits for all of its members and at the same time it practically has been financing different projects on sustainable development programs in the Värmland region. From Table 2, the profit-after-tax of KV is less when compared to that of others such as ICA, Axfood, and Ahold. For example in 2011, the profit after tax (as \% of net sales) was $0.2 \%$ for $\mathrm{KV}$ while it was $1.5 \%, 2.6 \%$, and $3.4 \%$ for ICA, AXFOOD, and Ahold respectively. However, $\mathrm{KV}$ is expanding in terms of potential market, number of members and customers' satisfaction which in turn strengthens its competiveness and sustainability.

Variety of factors motivates retailers to be engaged in non core business activities (such as environmental and social issues). These include new legislation, availability of capable investors, pressure from NGO and government bodies, media attention and information communication technologies. These factors have forced food retail outlets to show interest and commitment in the social and environmental impact of their operation [23]. Some of major motivating factors can be expressed as financial factors (long term investment), stakeholder's expectations (such as consumers willingness to buy environmentally friendly products), maintain reputation, top level management initiative, and societal factors. As indicated in Section 3.5, some main motivations have been identified for KV. Especially the managerial commitment, and members' willingness to preserve the culture and values of the cooperative and the consumers' awareness about the future trends enable KV to be completive in the region's food retail market. KV recognizes that its investment on environmental dimension has huge pay offs in the long term.

Food retailers face a number of challenges and risk while trying to implement sustainability initiatives because of the market dynamics and the competition they face around their environment [39]. Some of the challenges are: financial challenge (the cost associated with the implementation of sustainability programs), market challenge (consumers attitude towards sustainable products and price of the products), reliability of supply (difficulty in supplying the products in environmentally friendly and socially sound way [40], managerial barriers (lack of leadership involvement in incorporating sustainability issues in the core values at the corporate level). Such challenges are also noticed in the case of $\mathrm{KV}$ as indicated in Section 3.5.

This study revealed that small volumes and higher production costs are two main factors that force COOP stores to increase prices of eco-products than ordinary products. Usually, actions to lower the environmental impacts of retail activities require large scale and long term investments. For example, replacing old refrigerators and freezers in stores and installing new infrastructures in new stores are costly investment in short term, but have considerable positive impact in long term.

\section{Conclusions and Recommendation}

This study was initiated with the aim to assess the sustainable business management of a food retail business, Konsum Värmland (KV), operating in Sweden. The necessary data and information on history and status of $\mathrm{KV}$, values and strategy of $\mathrm{KV}$ towards sustainable business development, practical activities of KV that indicates the implementation of sustainable development programs and the motivation and challenges encountered KV during the implementation were gathered, interpreted and discussed. The implementation of sustainability initiatives was assessed mainly based on triple bottom line sustainability theory using identified sustainability indicators in environmental, social and economical dimensions.

The findings indicate that $\mathrm{KV}$ is a food retail firm which has CRAV certified stores and currently owned by 145,000 members. It has been running food retail services successfully for over a century. It incorporated the sustainability issues into its mission and values. It has been implementing sustainability programs in all the three dimensions i.e. environmental, social and economic dimensions of sustainable development. It provides environmentally friendly and quality food products at reasonably less prices. It sources its food items from suppliers known by their local brand names such as Värmlandsgris (supplying pigs), Värmlandslamm (supplying lambs), Värmlandskött (supplying cattle), Nästgård (supplying local products) and Svenska favoriter (supplying meatballs). KV perceives that integrating sustainability principles into its business operation satisfies the long term interest of its shareholders and stakeholders. This enables KV to be better positioned in its long-term market growth, profitability, legitimacy to operate and enhance its brand image in Värmland region of Sweden.

The major drives for incorporating sustainability initiatives in KV's business operations are leadership and employees' commitment, organizational core values, members' willingness to preserve the culture and values of the 
cooperative and the consumers' awareness about the future trends. On the other hand the major challenges to implement such sustainability initiatives are the increase in product price due to quality of produce and sustainability of its production systems; increase in logistics cost and emission especially during long winter time with much snow; the seasonality of local product so that it is difficult to meet customers demand during shortage of supply; and high cost of large scale investment in order to address the sustainability issues. KV has not produced yet comprehensive sustainability report.

In this study the sustainability indicators were not well quantified mainly due to lack of detailed information and data at KV level. Especially, data on emission, waste generation, and efficiency of utilization of resources such as energy, water, paper, vehicles and others were not obtained. Therefore further detailed study that promotes sustainable business development of KV with rich quantitative data is recommendable. This future study should also focus on reducing the major challenges by designing and implementing more effective approaches of addressing sustainability issues in $\mathrm{KV}$ and other food retail business firms.

\section{Acknowledgements}

The authors would like to thank personnel at Konsum Värmland and Coop Inköp \& Kategori AB for providing valuable information and sources of data during answering the interview questions.

\section{REFERENCES}

[1] FAO, "Sustainability Assessment of Food and Agriculture Systems: Guidelines,” Natural Resources Management and Environment Department, FAO, 2012. http://www.fao.org/fileadmin/user_upload/suistainability/ SAFA/SAFA_Guidelines_draft_Jan_2012.pdf

[2] World Commission on Environment and Development, "Our Common Future,” Oxford University Press, New York, 1987.

[3] A. Azapagic and S. Perdan, "Indicators of Sustainable Development for Industry: A General Framework,” Institution of Chemical Engineers, Manchester, 2000, pp. 243261.

[4] M. Wilson, "Corporate Sustainability: What Is It and Where Does It Come from?” Ivey Business Journal Online. March/April Edition, 2003, pp. 1-5.

http://wwwold.iveybusinessjournal.com/view_article.asp? intArticle_ID=405

[5] P. Dewhurst, "Product Design for Manufacture: Design for Disassembly,” Industrial Engineering, 1993. http://www.accessmylibrary.com/article-1G1-14437417/p roduct-design-manufacture-design.html

[6] P. Shrivastava, "Creating Sustainable Corporations," Business Strategy and the Environment, Vol. 4, No. 3, 1995, pp. 154-165. doi:10.1002/bse.3280040307
[7] CIAA, "Managing Environmental Sustainability in the European Food \& Drink Industries,” The Confederation of the Food \& Drink Industries of the EU, 2008. http://www.fooddrinkeurope.eu/uploads/publications_doc uments/brochure_CIAA_envi2008.pdf

[8] C. P. Timmer, "Do Supermarkets Change the Food Policy Agenda?” World Development, Vol. 37, No. 11, 2009, pp. 1812-1819. doi:10.1016/j.worlddev.2008.08.022

[9] P. McGoldrick, "Retail Marketing,” McGraw-Hill, Berkshire, 2002.

[10] J. Gustavsson, C. Ceberberg, R. Van Otterdijk and A. Meybeck, "Global Food Losses and Food Waste: Extent, Causes and Prevention,” Study Report, FAO, Rome, 2011.

[11] F. Szekely and M. Knirsch, "Responsible and Leadership and Corporate Social Responsibility: Metrics for Sustainable Performance,” European Management Journal, Vol. 23, No. 6, 2005, pp. 628-647.

[12] L. Maxey, “Can We Sustain Sustainable Agriculture? Learning from Small-Scale Producer-Suppliers in Canada and the UK," The Geographical Journal, Vol. 172, No. 3, 2006, pp. 230-244.

doi:10.1111/j.1475-4959.2006.00211.x

[13] J. Elkington, "Cannibals with Forks, the Triple Bottom Line of the 21st Century Business,” Capstone Publishing Ltd., Oxford, 1999.

[14] W. Norman and C. MacDonald, "Getting to the Bottom of 'Triple Bottom Line',” Business Ethics Quarterly, Vol. 14, No. 2, 2004, pp. 243-262.

[15] C. Hart, "Doing a Literature Review: Releasing the Social Science Research Imagination,” Sage, London, 1998.

[16] M. A. Berry and D. A. Rondinelli, "Proactive Corporate Environmental Management: A New Industrial Revolution," The Academy of Management Executives (19932005), Vol. 12, No. 2, 1998, pp. 38-50.

[17] G. H. Weaver, "Strategic Environmental Management: Using TQEM and ISO 14000 for Competitive Advantage," Wiley, New York, 1996.

[18] T. W. Zosel, "Pollution Prevention in the Chemical Industry. IN D.S. Opportunities for Innovation, Pollution Prevention,” Department of Commerce, National Institute of Standards and Technology, Washington DC, 1994.

[19] B. R. Allenby and D. J. Richards, "The Greening of Industrial Ecosystems,” National Academy of Engineering, Washington DC, 1994.

[20] E. Kirschner, "Full Cost Accounting for the Environment," Chemical Week, Vol. 154, No. 9, 1994, pp. 25-26.

[21] A. Carroll, “A Three Dimensional Conceptual Model of Corporate Performance," Academy of Management Review, Vol. 4, No. 4, 1979, pp. 497-505.

[22] H. Bowen, "Social Responsibilities of the Businessman," Harper, New York, 1953.

[23] P. Jones, D. Comfort and D. Hillier, "What's in Store? Retail Marketing and Corporate Social Responsibility," Marketing Intelligence and Planning, Vol. 25, No. 1, 2007, pp. 17-30. doi:10.1108/02634500710722371

[24] International Organization for Standardization, "ISO and Social Responsibility,” 2009. 
http://www.iso.org/obp/ui/\#iso:std:iso:26000:ed-1:v1:en

[25] M. Friedman, "The Social Responsibility of Business Is to Increase Its Profit," Times Magazine, 13 September 1970, New York, pp. 32-33 \&122-126.

[26] K. Davis, "The Case for and against Business Assumption of Social Responsibilities," Academy of Management Journal, Vol. 16, No. 2, 1973, pp. 312-322. doi:10.2307/255331

[27] Global Reporting Initiative, "Sustainability Reporting Guidelines, G3,” 21 April 2012. http://www.globalreporting.org/resourcelibrary/G3.1-Gui delines-Incl- Technical- Protocol.pdf

[28] C. Labuschagne, C. B. Alan and R. P. G. Van Erck, “Assessing the Sustainability Performances of Industries," Journal of Cleaner Production, Vol. 13, No. 4, 2005, pp. 373-385.doi:10.1016/j.jclepro.2003.10.007

[29] N. Nordmark, "The Distribution System of Konsum Värmland: A Preliminary Assessment Document,” Department of Energy and Technology, Uppsala, 2012.

[30] KV, “Annual Activity Report of Konsum Värmland,” 2011.

http://www.konsumvarmland.se/index.php?option=com_c ontent\&task $=\mathrm{v}$ iew\&id=203\&Itemid $=171$

[31] ICA, “Year-End Report of ICA AB,” Stockholm, 2011. http://www.ica.se/Global/Om\%20ICA/Pdf/ICA\%20Yearend_report \%202011\%20120215.pdf

[32] KF, “Sustainability Report,” Koperativa Förebundet, Annual Report, 2011. http://www.coop.se/Global/KF/Finansiell\%20information /KF_HR11_indexerad.pdf

[33] Ahold, "Financial Statements," Ahold Annual Report, 2011, pp. 69-138. http://2011yearreview .ahold.com/downloads/Ahold-AR2011-Financials.pdf

[34] L. Newman, "The Virtuous Cycle: Incremental Changes and Process-Based Sustainable Development," Sustainable Development, Vol. 15, No. 4, 2007, pp. 267-274. doi:10.1002/sd.317

[35] J. Pretty, "The Living Land: Agriculture, Food Community Regeneration in Rural Europe,” Earth Scan Publication, London, 1998.

[36] J. P. Reganold, R. I. Papendick and J. F. Parr, "Sustainable Agriculture in the USA,” In: P. Conford, Ed., A Future for the Land: Organic Practice from a Global Perspective, Green Books Ltd., Bideford, 1992, pp. 91-101.

[37] M. Zetterberg, "Can Values Drive Values for Sustainable Business? An Analyzing and Interpreting Case Study of Konsume Värmland Value-Creation,” M.S. Thesis, Karlstad University, Karlstad, 2007.

[38] S. D. Elder, H. Zerriffi and P. L. Billon, "Effects of Fair Trade Certification on Social Capital: The Case of Rwandan Coffee Producers," World Development, Vol. 40, No. 11, 2012, pp. 2355-2367. doi:10.1016/j.worlddev.2012.06.010

[39] Deloitte, "Feeling the Squeeze Global Powers of Retailing," 2009 http://public.deloitte.com/media/0460/2009GlobalPowers ofRetail_FINAL2.pdf

[40] M. Almaani, P. Aylwinblanco, C. Barbato, D. Benavides, M. Burman, P. Cacouris, C. Palacios, J. Sorensen, T. Sorgeloose, C. Vanier and G. Vemali, "Retailers Communication to Promote Sustainable Consumption,” UNEP-HEC School of Management, Paris, 2004. 